\title{
Erratum: Elshazli et al. Laser Surface Modification of TC21 $(\alpha / \beta)$ Titanium Alloy Using a Direct Energy Deposition (DED) Process. Micromachines 2021, 12, 739
}

\author{
Ahmed Magdi Elshazli ${ }^{1}$, Ramadan N. Elshaer ${ }^{2}$, Abdel Hamid Ahmed Hussein ${ }^{3}$ and Samar Reda Al-Sayed ${ }^{1, *}$ D \\ 1 Department of Engineering Applications of Laser, National Institute of Laser Enhanced Sciences (NILES), \\ Cairo University, Giza 12611, Egypt; eg.engshazly@yahoo.com \\ 2 Department of Mechanical Engineering, Tabbin Institute for Metallurgical Studies (TIMS), Cairo-Egypt, \\ Helwan 11731, Egypt; ramadan_elshaer@yahoo.com \\ 3 Department of Metallurgy, Faculty of Engineering, Cairo University, Giza 12611, Egypt; \\ aahussein41@yahoo.com \\ * Correspondence: sreda@niles.edu.eg; Tel.: +20-10-6654-8019
}

check for updates

Citation: Elshazli, A.M.; Elshaer, R.N.; Hussein, A.H.A.; Al-Sayed, S.R. Erratum: Elshazli et al. Laser Surface Modification of TC21 $(\alpha / \beta)$ Titanium Alloy Using a Direct Energy Deposition (DED) Process. Micromachines 2021, 12, 739 . Micromachines 2021, 12, 1078. https:/ / doi.org/10.3390/mi12091078

Received: 19 August 2021 Accepted: 31 August 2021

Published: 7 September 2021

Publisher's Note: MDPI stays neutral with regard to jurisdictional claims in published maps and institutional affiliations.

Copyright: (c) 2021 by the authors. Licensee MDPI, Basel, Switzerland. This article is an open access article distributed under the terms and conditions of the Creative Commons Attribution (CC BY) license (https:/ / creativecommons.org/licenses/by/ $4.0 /)$.
In the original article [1], there was a mistake in Figure 9 as published. It was repeated with Figure 14. The corrected Figure 9 appears below.

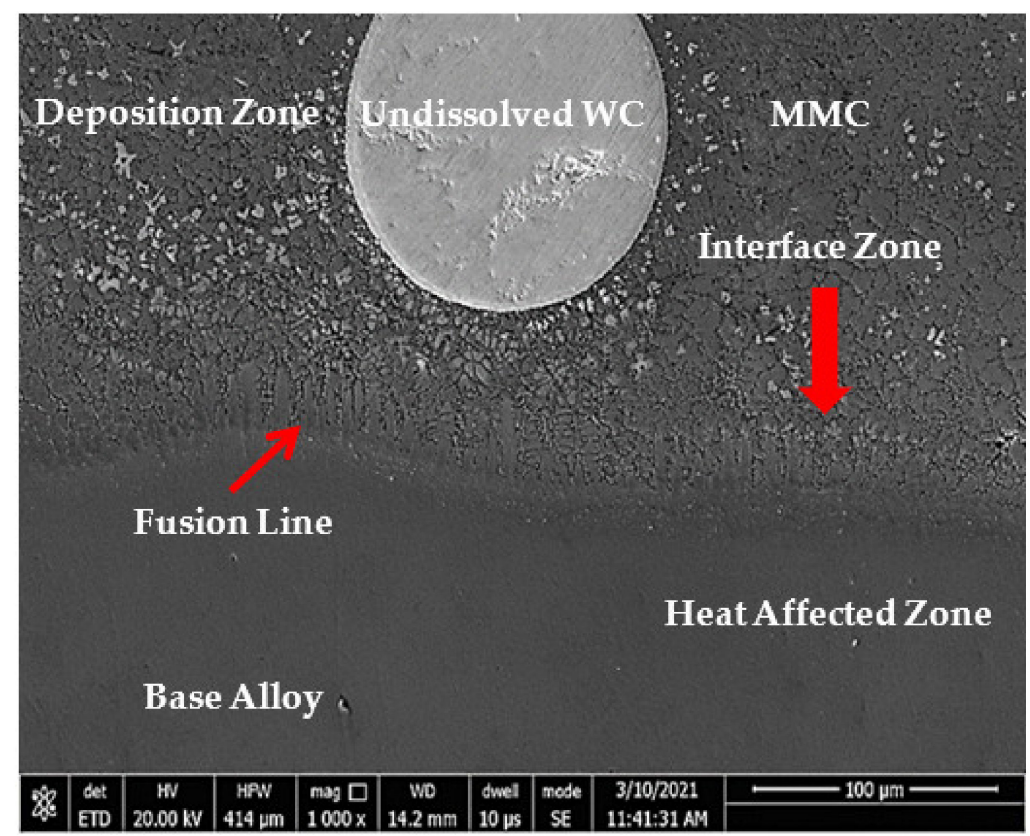

Figure 9. FESEM micrograph of S2 cross section of the whole deposited layer showing three different zones of deposition, interface and HAZ.

The authors apologize for any inconvenience caused and state that the scientific conclusions are unaffected. The original article has been updated.

Conflicts of Interest: The authors declare no conflict of interest.

\section{Reference}

1. Elshazli, A.M.; Elshaer, R.N.; Hussein, A.H.A.; Al-Sayed, S.R. Laser Surface Modification of TC21 $(\alpha / \beta)$ Titanium Alloy Using a Direct Energy Deposition (DED) Process. Micromachines 2021, 12, 739. [CrossRef] [PubMed] 